\title{
Spatial distribution of wood volume in Brazilian savannas
}

\author{
EDUARDA M.O. SILVEIRA ${ }^{1,2}$, ALINY A. DOS REIS ${ }^{1,3}$, MARCELA C.N.S. TERRA ${ }^{1}$, KIERAN D. WITHEY ${ }^{4}$, JOSÉ \\ M. DE MELLO ${ }^{1}$, FAUSTO W. ACERBI-JÚNIOR ${ }^{1}$, ANTONIO CARLOS FERRAZ FILHO ${ }^{5}$ and CARLOS R. MELLO ${ }^{6}$
}

\author{
${ }^{1}$ Forest Science Department - DCF, Federal University of Lavras - UFLA, University Campus, 37200-000 Lavras, MG, Brazil \\ ${ }^{2}$ SILVIS Lab, Department of Forest and Wildlife Ecology, University of Wisconsin, \\ 1630 Linden Drive, Madison, WI, 53706, United States of America \\ ${ }^{3}$ Interdisciplinary Center of Energy Planning - NIPE, University of Campinas - UNICAMP, \\ 330 Cora Coralina Street, University City, 13083-896 Campinas, SP, Brazil \\ ${ }^{4}$ Lancaster Environment Centre (LEC), Lancaster University, Lancaster, LA1 4YQ, United Kingdom \\ ${ }^{5}$ CPCE, Federal University of Piauí, Manoel Gracindo Avenue, Km 01, 64900-000 Bom Jesus, PI, Brazil \\ ${ }^{6}$ Water Resources Department, Federal University of Lavras - UFLA \\ University Campus, 37200-000 Lavras, MG, Brazil
}

Manuscript received on June 28, 2018; accepted for publication on October 1, 2018

\begin{abstract}
How to cite: SILVEIRA EMO, REIS AA, TERRA MCNS, WITHEY KD, MELLO JM, ACERBI-JÚNIOR FW, FERRAZ FILHO AC AND MELLO CR. 2019. Spatial distribution of wood volume in Brazilian savannas. An Acad Bras Cienc 91: e20180666. DOI 10.1590/0001-3765201920180666.
\end{abstract}

\begin{abstract}
Here we model and describe the wood volume of Cerrado Sensu Stricto, a highly heterogeneous vegetation type in the Savanna biome, in the state of Minas Gerais, Brazil, integrating forest inventory data with spatial-environmental variables, multivariate regression, and regression kriging. Our study contributes to a better understanding of the factors that affect the spatial distribution of the wood volume of this vegetation type as well as allowing better representation of the spatial heterogeneity of this biome. Wood volume estimates were obtained through regression models using different environmental variables as independent variables. Using the best fitted model, spatial analysis of the residuals was carried out by selecting a semivariogram model for generating an ordinary kriging map, which in turn was used with the fitted regression model in the regression kriging technique. Seasonality of both temperature and precipitation, along with the density of deforestation, explained the variations of wood volume throughout Minas Gerais. The spatial distribution of predicted wood volume of Cerrado Sensu Stricto in Minas Gerais revealed the high variability of this variable (15.32 to $\left.98.38 \mathrm{~m}^{3} \mathrm{ha}^{-1}\right)$ and the decreasing gradient in the southeast-northwest direction.
\end{abstract}

Key words: cerrado sensu stricto, forest inventory, geostatistics, regression kriging, volumetry.

\section{INTRODUCTION}

The Brazilian Savanna biome, also known as Cerrado, occupies about 2.5 million square kilometres, which represents approximately $25 \%$

Correspondence to: Aliny Aparecida dos Reis

E-mail: alinyreis@hotmail.com

ORCID: https://orcid.org/0000-0002-7115-1485 of the country's territory. This biome is among the most endangered eco-regions in the world due to high conversion rates and few protected areas (Hoekstra et al. 2005), and is considered one of the world's biodiversity hotspots (Myers et al. 2000). Its large area extent, climatic variability, vegetation mosaics and proximity to other tropical biomes result in high heterogeneity of the vegetation types 
in this biome (Silva et al. 2006), ranging from dry grassland to densely wooded Savanna (Ferreira et al. 2004, Arantes et al. 2016).

Since the 1970s this biome has suffered large losses of its natural vegetation due to agricultural expansion (Fearnside 2001, Silva et al. 2006). Currently, the rate of deforestation is about $1.6 \%$ per year (Arantes et al. 2016), leading to large-scale conversion of native vegetation to agricultural land, which has already affected more than $40 \%$ of the original area of this biome (Ferreira et al. 2004, Sano et al. 2010). This high conversion rate of primary vegetation threatens the stability of the ecosystem, along with ecological services, such as carbon sequestration and climate regulation (Schwieder et al. 2016).

Good indicators of priority areas for conservation require accurate estimates of important factors, such as wood volume (Gizachew et al.2016). However, due to the great heterogeneity of Brazilian Savannas, estimates of wood volume of its remnants over large geographic regions are expensive, time consuming, and labour intensive. Thus, it is necessary to develop new techniques and approaches for estimating wood volume over large areas that combine field-based forest inventory data with more robust techniques in solving problems previously resolved by traditional statistical modeling.

Traditionally, information of diameter and total height of trees measured in field plots established according to a pre-defined sampling system are used to estimate wood volume using classical statistical methods. However, these procedures assume that the spatial variability of the variables of interest are random and do not consider them to be spatially dependent (Guedes et al. 2015). Previous studies have shown that biometric variables are spatially structured and, therefore, this spatial dependence should not be disregarded in the statistical analyses (Alvarenga et al. 2012, Scolforo et al. 2015). To solve this issue, several geostatistical methods and techniques have been developed over the last fifty years, and are widely used in forest management, leading to significant improvements in estimation accuracy of wood volume (Alvarenga et al. 2012, Reis et al. 2015). Among these geostatistical techniques, kriging is the most widely used (Scolforo et al. 2016). However, in highly heterogeneous areas, like Brazilian Savannas, more robust techniques are necessary, such as those based on multivariate kriging, e.g. regression kriging (Galeana-Pizaña et al. 2014, Meng et al. 2009, Viana et al. 2012).

Regression kriging is a hybrid method that includes the combination of a linear regression between the target variable and auxiliary variables and ordinary kriging of the regression residuals, which is then used to correct the map developed based on the regression model (Palmer et al. 2009, Viana et al. 2012). The regression model should be able to capture the spatial behaviour of the target variable (Mello et al. 2013), assuming that the residuals of the regression model are spatially distributed and combines information from the relationships between the target and auxiliary variables through deterministic models, local components and error (Scolforo et al. 2016).

Here, we model the wood volume of Brazilian Savannas in the state of Minas Gerais, southeast Brazil, using spatial and environmental datasets, multivariate regression and geostatistical regression kriging. This study contributes to a better understanding of the variables that affect the volumetric spatial distribution of Brazilian Savanna as well as improving our knowledge of the spatial heterogeneity of this biome.

\section{MATERIALS AND METHODS}

\section{STUDY AREA AND DATA COLLECTION}

This study was conducted in a Brazilian Savanna vegetation type, known as Cerrado Sensu Stricto, which falls within the state borders of Minas 
Gerais. According to the Brazilian Institute of Geography and Statistics (IBGE), it represents an area of approximately $54,500 \mathrm{~km}^{2}$. Cerrado Sensu Stricto is a type of woodland Savanna characterized by vegetation dominated by trees and shrubs often 3-8 $\mathrm{m}$ tall with more than $30 \%$ crown cover and a continuous grass layer (Oliveira-Filho and Ratter 2002). The Cerrado Sensu Stricto in the state of Minas Gerais is located between latitudes $-14.25^{\circ}$ and $-21.50^{\circ}$ south and between longitudes $-41.80^{\circ}$ and $-50.91^{\circ}$ west (Figure 1).

The average annual temperature is between 21 and $23^{\circ} \mathrm{C}$. Rainfall is highly seasonal, concentrated between the months of October and March, with annual averages between 1,200 and 1,800 mm of rainfall. The topographic conditions present altitudes ranging between 900 and 1500 meters.

A total of 641 plots of $1000 \mathrm{~m}^{2}(10 \times 100 \mathrm{~m})$ in 57 remnants of Cerrado Sensu Stricto were sampled
(Figure 1), during the Project "Forest Inventory of Minas Gerais", conducted by the Universidade Federal de Lavras (Federal University of Lavras, UFLA), in 2006 and 2007 (Scolforo et al. 2008). During the field surveys, the diameter at breast height (DBH; $1.3 \mathrm{~m}$ ) and the total height of all trees with a minimum DBH of $5 \mathrm{~cm}$ were measured. Total wood volume for all the trees was estimated by applying Eq. 1, developed by Rufini et al. (2010) for Cerrado Sensu Stricto.

$\mathrm{V}=\mathrm{e}^{(-9.7289673246+2.4207715832 * \ln (\mathrm{DBH})+0.4608810281 * \ln (\mathrm{H}))}$

where $\mathrm{V}$ is the volume $\left(\mathrm{m}^{3}\right) ; e$ is the base of the natural logarithm; In is the natural logarithm; $\mathrm{DBH}$ is the diameter measured at 1.3 meters above the ground $(\mathrm{cm})$; and $\mathrm{H}$ is the total tree height $(\mathrm{m})$.

We used 19 climatic variables (Table I; 1 $\mathrm{km}^{2}$ spatial resolution) which were acquired from WorldClim (Hijmans et al. 2005). We used

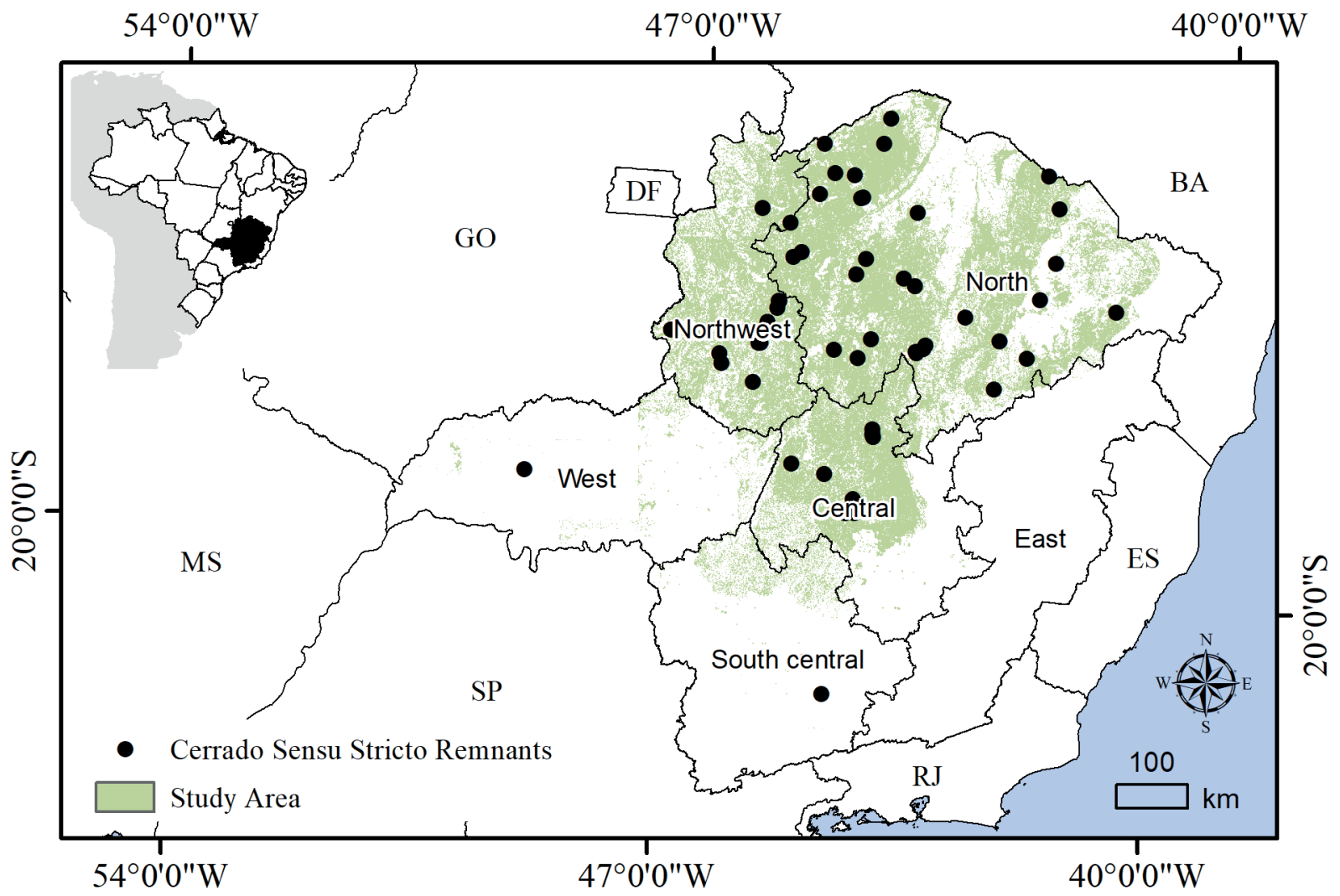

Figure 1 - Location of the state of Minas Gerais in Brazil and remnants of Cerrado Sensu Stricto measured by the project Forest Inventory of Minas Gerais. 
additional spatial variables, and a topographic and deforestation density map generated by the Project "Forest Inventory of Minas Gerais - Monitoring of Native Flora 2006-2007”. The deforestation density map was developed by Carvalho and Scolforo (2008), who developed a computational algorithm for semi-automatic detection and segmentation of areas that were subjected to drastic land-use/cover changes.

\section{WOOD VOLUME MODELLING AND REGRESSION KRIGING}

We used a stepwise regression technique based on the Akaike information criterion (AIC) to select the most significant independent variables to build the wood volume model. The total database was randomly divided into a fitting set $(70 \%$ of the database) and a validation set (30\% of the database). The best model was subjected to successive variance inflation factor (VIF) tests for the removal of those variables with VIF values greater than or equal to 10 , which ensures that the final model is free of multicollinearity (Dormann et al. 2012).

To spatialize the model residuals, firstly we verified whether the data were non-biased and isotropic in different directions. We then spatialized the residuals obtained with the multivariate model using ordinary kriging by fitting theoretical semivariogram models (Gaussian, Spherical, and Exponential) using the weighted least squares method. The selection and validation of the best semivariogram model was based on reduced mean error (ER) and standard deviation of reduced mean error (SDE), which were calculated on the basis of the cross validation process described by Cressie (1991) and McBratney and Webster (1986).

Semivariograms express the variation of a given attribute as a function of the distance between the points in the sampling field. The total variance of the attribute is dismembered into different distances and used to estimate the spatial structure of the variance. The semivariance is
TABLE I

Variables used for modelling the wood volume in Cerrado Sensu Stricto in the state of Minas Gerais, southeast Brazil.

\begin{tabular}{|c|c|}
\hline Variables & Description \\
\hline Bio 1 & Annual Mean Temperature $\left({ }^{\circ} \mathrm{C}\right)$ \\
\hline Bio 2 & Mean Diurnal Range (Mean of monthly) $\left({ }^{\circ} \mathrm{C}\right)$ \\
\hline Bio 3 & Isothermality $(\mathrm{BIO} 2 / \mathrm{BIO} 7)(* 100)\left({ }^{\circ} \mathrm{C}\right)$ \\
\hline Bio 4 & $\begin{array}{l}\text { Temperature Seasonality (standard deviation } \\
\qquad * 100)\left({ }^{\circ} \mathrm{C}\right)\end{array}$ \\
\hline Bio 5 & Max Temperature of Warmest Month $\left({ }^{\circ} \mathrm{C}\right)$ \\
\hline Bio 6 & Min Temperature of Coldest Month $\left({ }^{\circ} \mathrm{C}\right)$ \\
\hline Bio 7 & $\begin{array}{l}\text { Temperature Annual Range (BIO5-BIO6) } \\
\qquad\left({ }^{\circ} \mathrm{C}\right)\end{array}$ \\
\hline Bio 8 & Mean Temperature of Wettest Quarter $\left({ }^{\circ} \mathrm{C}\right)$ \\
\hline Bio 9 & Mean Temperature of Driest Quarter $\left({ }^{\circ} \mathrm{C}\right)$ \\
\hline Bio 10 & Mean Temperature of Warmest Quarter $\left({ }^{\circ} \mathrm{C}\right)$ \\
\hline Bio 11 & Mean Temperature of Coldest Quarter $\left({ }^{\circ} \mathrm{C}\right)$ \\
\hline Bio 12 & Annual Precipitation (mm) \\
\hline Bio 13 & Precipitation of Wettest Month (mm) \\
\hline Bio 14 & Precipitation of Driest Month (mm) \\
\hline Bio 15 & $\begin{array}{c}\text { Precipitation Seasonality (Coefficient of } \\
\text { Variation) }(\mathrm{mm})\end{array}$ \\
\hline Bio 16 & Precipitation of Wettest Quarter (mm) \\
\hline Bio 17 & Precipitation of Driest Quarter (mm) \\
\hline Bio 18 & Precipitation of Warmest Quarter (mm) \\
\hline Bio 19 & Precipitation of Coldest Quarter (mm) \\
\hline Dec & Declivity (\%) \\
\hline Elev & Elevation (m) \\
\hline Lat & Latitude \\
\hline Long & Longitude \\
\hline Prec & Annual Mean Precipitation (mm) \\
\hline Temp & Annual Mean Temperature $\left({ }^{\circ} \mathrm{C}\right)$ \\
\hline Dd & Deforestation density (Number/m²) \\
\hline
\end{tabular}

characterized by three parameters: sill, range and nugget effect (Isaaks and Srivastava 1988). Sill is the plateau reached by the values of semivariance, and indicates the amount of variation that can be explained by the spatial structure of the data. Range is the distance at which the semivariogram reaches the plateau, indicating the distance at which the 
points are spatially correlated. The nugget effect is the combination of sampling errors and variations on small scales, whose distance values are smaller than the shortest distance between the points sampled.

The selected semivariogram model was used for the ordinary kriging of the regression residuals, introducing a stochastic aspect to the wood volume maps. For the regression kriging application, continuous georeferenced cells with dimensions of $100 \times 100$ m were created for the Cerrado Sensu Stricto vegetation in the state of Minas Gerais. In each of these cells, the variables selected in the multivariate model were extracted and the regression model was applied to them, generating the global map of wood volume. The final step was the correction of this map by adding the residual ordinary kriging map.

The accuracies of predicted wood volume maps were evaluated using Root Mean Square Error (RMSE) calculated in percentage based on field-based inventory wood volume estimates with the validation set. We used R (R Core Team 2016) and ArcGis version 10.1 (Esri 2010) for the analyses.

\section{RESULTS AND DISCUSSION}

\section{EXPLORATORY ANALYSIS}

The statistics of the wood volume $\left(\mathrm{m}^{3} \mathrm{ha}^{-1}\right)$ obtained from field-based forest inventory indicate that average $\left(48.5 \mathrm{~m}^{3} \mathrm{ha}^{-1}\right)$ and median $\left(44.7 \mathrm{~m}^{3}\right.$ $\mathrm{ha}^{-1}$ ) values are close to one another, indicating a symmetry in the distribution of the wood volume data $\left(\mathrm{m}^{3} \mathrm{ha}^{-1}\right)$. The minimum value was $15.9 \mathrm{~m}^{3}$ $\mathrm{ha}^{-1}$ and the maximum value was $107.2 \mathrm{~m}^{3} \mathrm{ha}^{-}$ ${ }^{1}$, which led to a high coefficient of variation (42.8\%), and thus, a high variability of the wood volume throughout this biome. Alvarenga et al. (2012) and Reis et al. (2015) studied remnants of Cerrado Sensu Stricto in the northern region of the state of Minas Gerais, and found a coefficient of variation for wood volume per hectare of $72.2 \%$ and $60.9 \%$, respectively. Thus, the results found here corroborate these studies, confirming the high volumetric variability of Cerrado Sensu Stricto in the state of Minas Gerais. Scolforo et al. (2008) reported that this vegetation type presents great variation in its wood volume, both within the same remnant and among remnants, due to the differences in tree density, which can range from 407 to 2316 individuals per hectare in the state of Minas Gerais.

\section{WOOD VOLUME MODELLING}

All parameters used in our multivariate regression model had significant coefficients (Table II) and the residuals were normally distributed (Shapiro-Wilk, $\mathrm{p}=0.98)$, with a coefficient of determination $\left(\mathrm{R}^{2}\right)$ of 0.55 and a mean absolute error (MAE) of $34.5 \%$. Figure 2 illustrates the one-to-one relationship between observed and estimated wood volume of Cerrado Sensu Stricto as obtained using the selected multivariate regression model. This model resulted in a predictable dispersion of the observed values in relation to the field-measured values close to the axis of $45^{\circ}$, indicating increased predicted value precision in comparison to observed values.

The coefficient of determination $\left(\mathrm{R}^{2}\right)$, as well as the mean absolute error (MAE), are considered

\section{TABLE II}

Coefficients estimated by the regression model and their statistical significance.

\begin{tabular}{cccc}
\hline Coefficients & Variable & Values & p-value \\
\hline b0 & Intercept & -395.6202 & 0.0073 \\
b1 & Bio 10 & 11.9302 & 0.0076 \\
b2 & Bio 17 & 0.3919 & 0.0911 \\
b3 & Bio 3 & 49.0357 & 0.0039 \\
b4 & Temp & -8.9337 & 0.0105 \\
b5 & Dd & 2.8011 & 0.0664 \\
\hline
\end{tabular}

Bio $10=$ Mean Temperature of Warmest Quarter $\left({ }^{\circ} \mathrm{C}\right)$; Bio $17=$ Precipitation of Driest Quarter (mm); Bio $3=$ Isothermality (\%); Temp = Annual Mean Temperature $\left({ }^{\circ} \mathrm{C}\right) ; \mathrm{Dd}=$ Deforestation density (Number $/ \mathrm{m}^{2}$ ). 


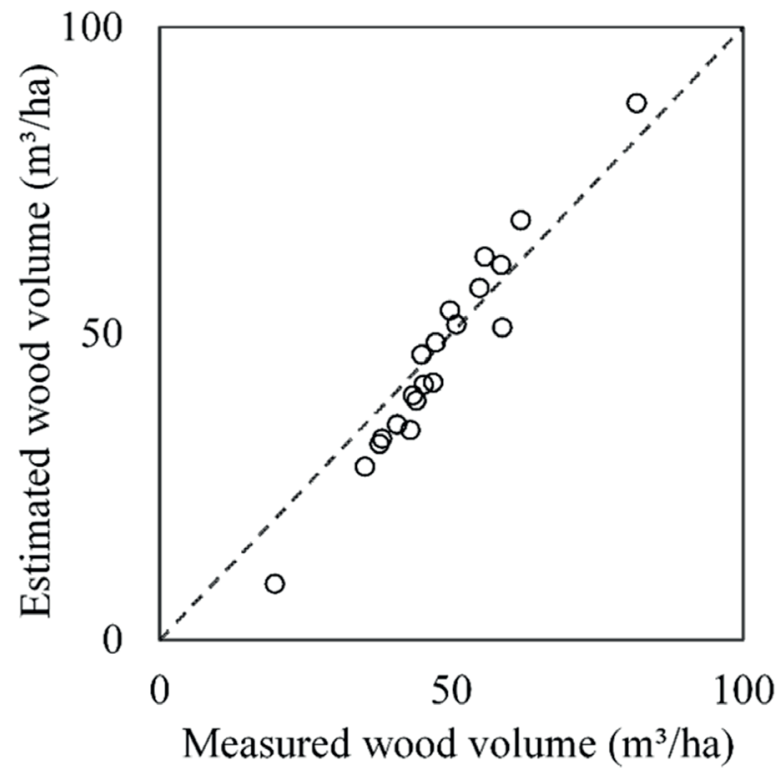

Figure 2 - Scatterplots of the predicted vs. observed wood volume in Cerrado Sensu Stricto in the state of Minas Gerais.

acceptable due to the wide variation found for the target variable in this region. This wide variation reflects the heterogeneity of the natural conditions of the Cerrado Sensu Stricto remnants in the state of Minas Gerais, which directly affects the wood volume (Scolforo et al. 2008). In addition, it is important to note that the wood volume values do not only respond to the environmental conditions considered, but also to other environmental variables, such as chemical and physical soil characteristics (Berner and Law 2016), as well as structural conditions of the remnant, such as different vegetation successional stages with different age structures (Schwieder et al. 2016).

In general, climate seasonality (in terms of both temperature (Bio 3, Bio 10, and Temp) and precipitation (Bio 17)), and deforestation are the main drivers of the variation in wood volume in the state of Minas Gerais (Figure 3). These specific climate variables, mainly precipitation seasonality, mean temperature, and isothermality (Bio 3) - a measure of reduced temperature seasonality increase environmental stress in the north of the state, and are directly related to the limitations of tree growth and number of trees, as a consequence of reduced water availability (Esquivel-Muelbert et al. 2016, Terra et al. 2018).

On the other hand, deforestation detected between 2006 and 2007 has a direct influence on the wood volume, since it implies significant losses in the vegetation stock (Arantes et al. 2016). These deforestation events are generally concentrated to productive areas, which makes them more desirable for wood exploitation. Rocha et al. (2011) analysed the spatial distribution of deforestation in the Cerrado from 2002 to 2009 in order to understand the processes responsible for the transformation of this biome. They found that $70 \%$ of deforestation was concentrated in only 100 municipalities and occurred mainly in areas of dense vegetation and predominantly flat relief, favouring the advance of mechanized agriculture and, to a lesser extent, extensive livestock. This tendency for agricultural frontiers to occur in areas of dense vegetation with greater biomass was also observed by Aguiar et al. (2012) for the Brazilian Amazon.

\section{REGRESSION KRIGING}

The variographic analysis indicates that the residuals of the model were spatially structured (nugget effect $=147.38 \mathrm{~m}^{6} \mathrm{ha}^{-2}$, sill $=480.73 \mathrm{~m}^{6}$ $\mathrm{ha}^{-2}$, and range $\left.=20.71 \mathrm{~m}\right)($ Figure 4$)$, and the spherical model presented the best performance of all fitted models $\left(E R=0.019 \mathrm{~m}^{3} \mathrm{ha}^{-1} ; \mathrm{SER}=0.920\right.$ $\left.\mathrm{m}^{3} \mathrm{ha}^{-1}\right)$. The degree of spatial dependence of the volume residual variable (GDE\%) represents the magnitude of the structure of spatial dependence, and can be obtained from the ratio (sill)/(nugget effect + sill). According to Cambardella et al. (1994), if the GDE is greater than $75 \%$, there is a strong spatial correlation between the points sampled. In this study, the GDE was equal to $78.2 \%$, which indicates a strong spatial dependence of the residuals. The GDE also indicates that from the $45 \%\left(1-\mathrm{R}^{2}\right)$ of the variation in wood volume that 

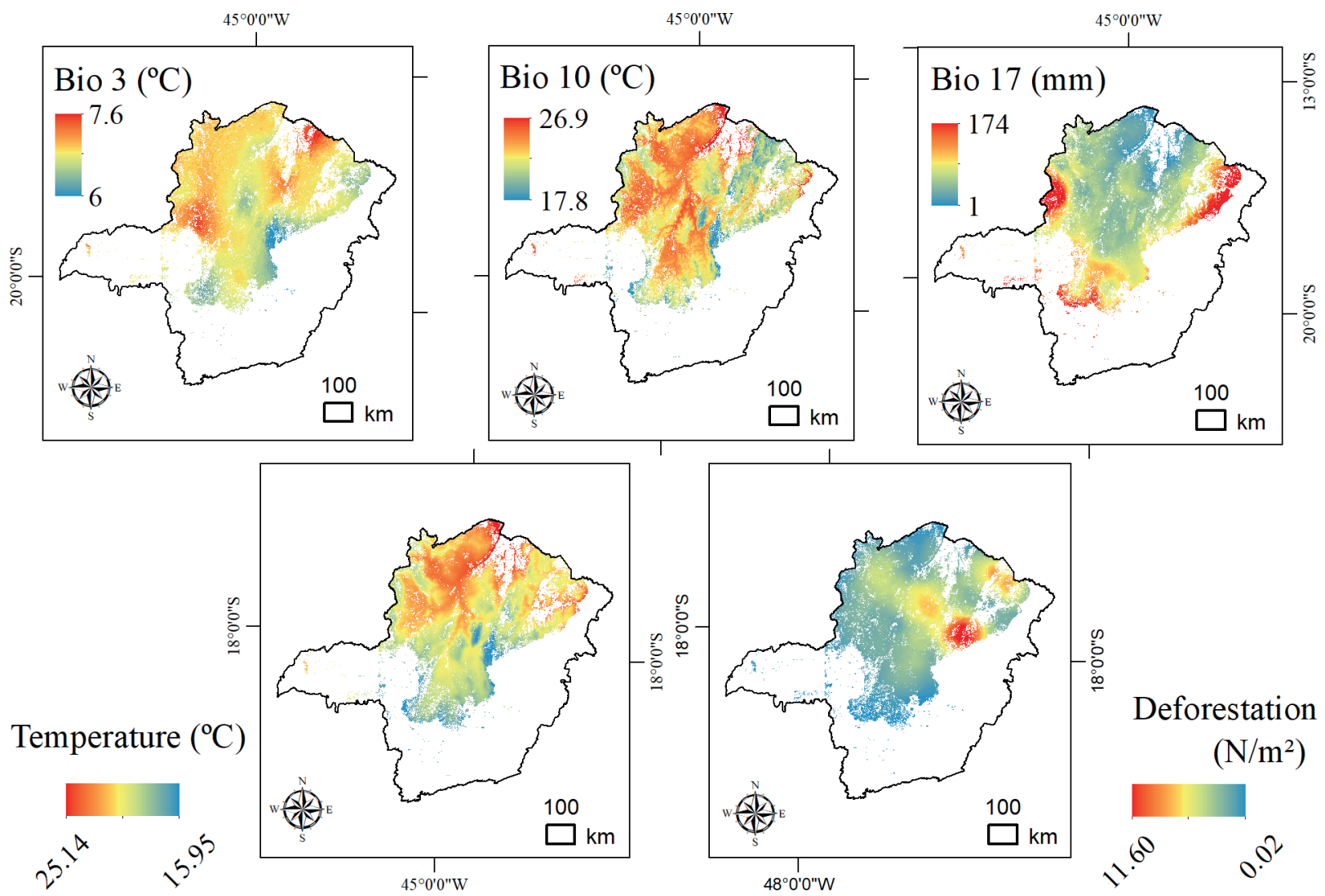

Figure 3 - Selected variables by multivariate regression model for wood volume estimation: Bio 3= Isothermality; Bio $10=$ Mean Temperature of Warmest Quarter $\left({ }^{\circ} \mathrm{C}\right)$; Bio $17=$ Precipitation of Driest Quarter $(\mathrm{mm})$; Temp=Annual Mean Temperature and Dd= Deforestation density.

were not explained by the regression model, 78\% were explained by the spatial model. Therefore, $35 \%$ of the original variation in wood volume were explained by the spatial component.

From the spatial distribution map of the residuals (Figure 5), it is possible to observe a balance between the under and overestimates, meaning that the model is adequate as there is no bias produced by the regression model. Meusburger et al. (2012) and Mello et al. (2013) both applied regression kriging for rainfall erosivity mapping in Switzerland and Brazil, respectively, and concluded that the residuals should have a balanced, trendless spatial distribution, so that the regression kriging can be more expressive. In addition to this characteristic, it is important to note that the low values of estimation errors, both

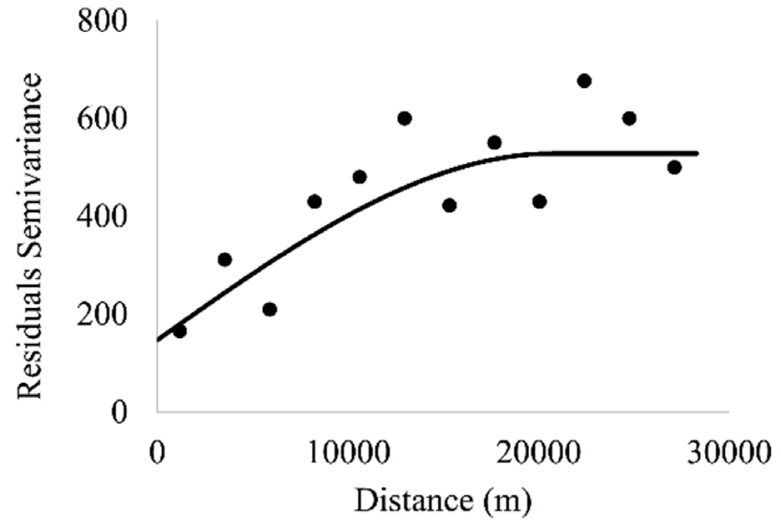

Figure 4 - Theoretical and experimental univariate semivariogram for wood volume residuals $\left(\mathrm{m}^{3} / \mathrm{ha}\right)$ as a function of environmental variables in Cerrado Sensu Stricto of the state of Minas Gerais.

underestimates (negative values) and overestimates (positive values), demonstrate not only the good performance of the multivariate regression model, 


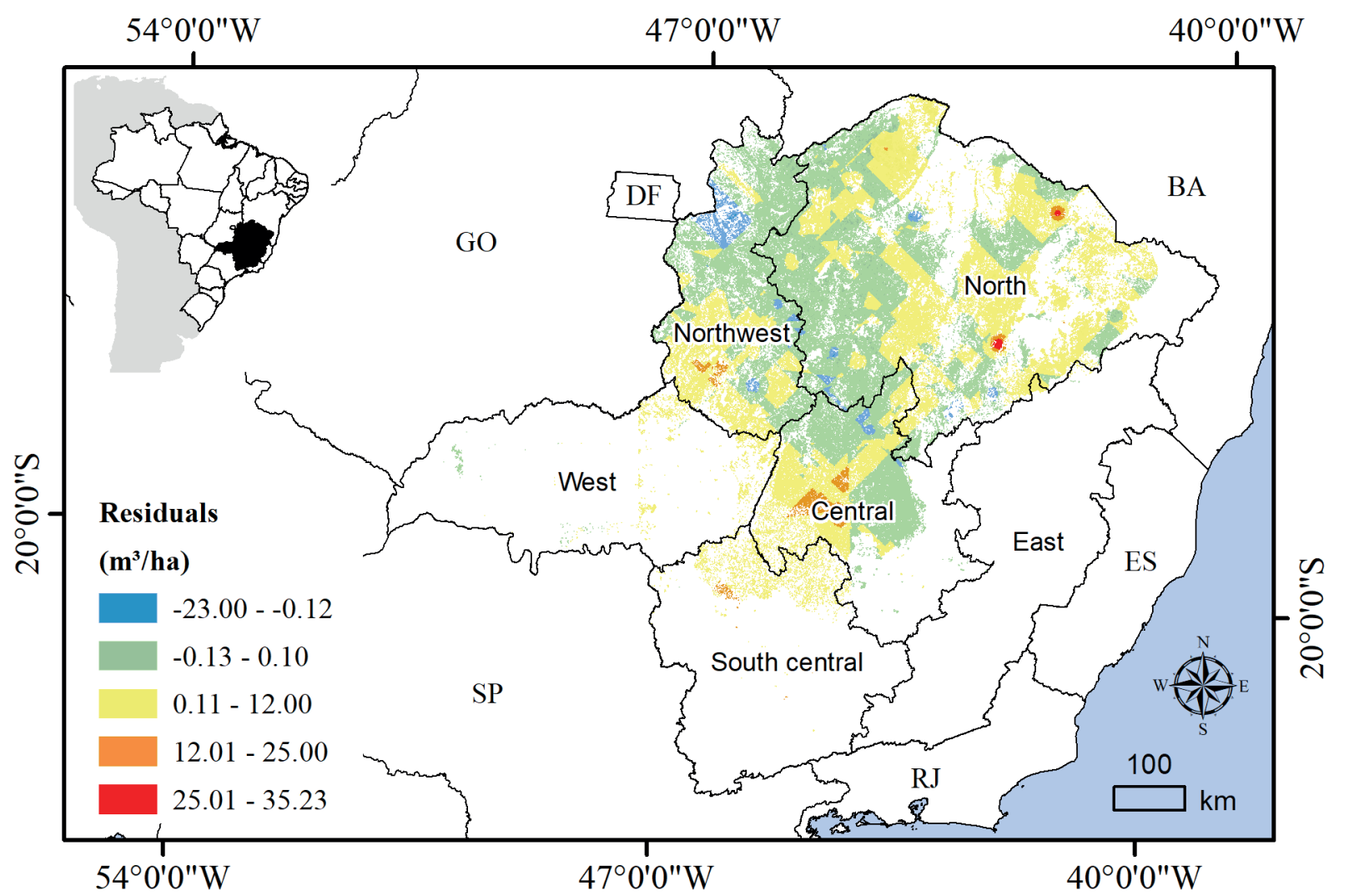

Figure 5 - Spatial distribution of wood volume residuals in Cerrado Sensu Stricto in the state of Minas Gerais.

but also the good performance of the ordinary kriging map of wood volume residuals.

\section{SPATIAL DISTRIBUTION OF WOOD VOLUME}

Both the global map generated by the regression model (RMSE $=11.6 \%$ ) (Figure 6) and the map corrected by the regression kriging technique (Figure 7) revealed a decrease in the wood volume from the middle towards the northern portions of the state. This is primarily related to the effects of the seasonality of precipitation (Esquivel-Muelbert et al. 2016), as indicated by the regression model. Furthermore, low soil water availability in these regions (Skorupa et al. 2012) also represents a limiting factor for the growth of biometric characteristics, leading to low wood volume values (Wagner et al. 2012).

The western portion of the Central region of the state and the southern portion of the Northeast region hold the remnants with the highest wood volumes, ranging from 45 to $98.2 \mathrm{~m}^{3} \mathrm{ha}^{-1}$. These regions have increased water availability, which provides more favourable conditions for plant growth (see Bio 17 variable in Figure 2). In the northern part of the state lies a region with wood volumes of less than $30 \mathrm{~m}^{3} \mathrm{ha}^{-1}$. These areas have experienced anthropogenic disturbances, such as exploitation of vegetation for charcoal production, cattle grazing, and conversion for agricultural practices and they are in an advanced degradation stage leading to lower wood volume in this region.

The low wood volume obtained for the middle region of the state occurred due to climatic effects related to a geographical barrier, which generates an unfavourable situation for vegetation growth. This geographical barrier consists of an extensive mountain range known as the Espinhaço Range, which produces an orographic effect 


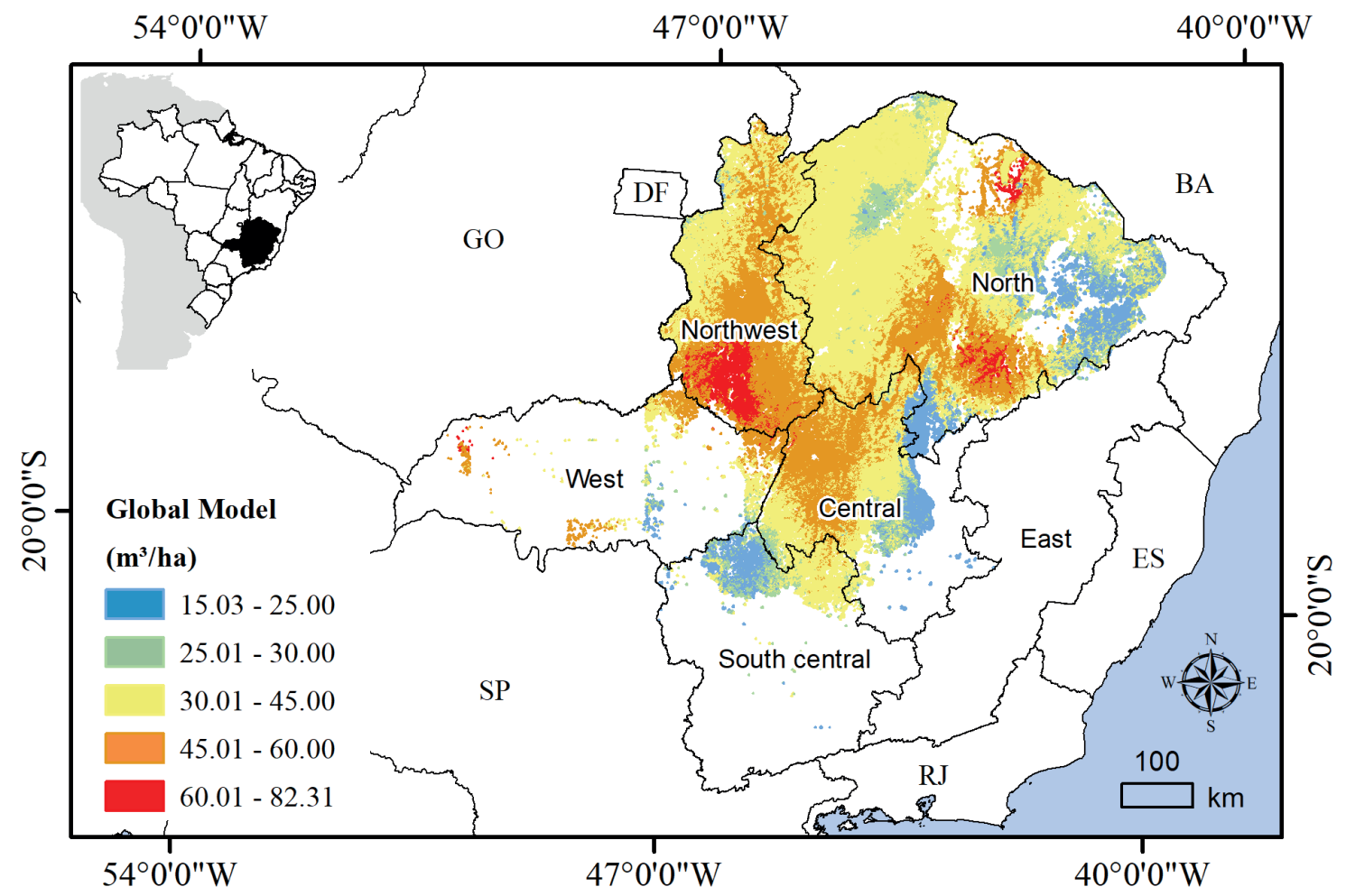

Figure 6 - Global model for wood volume $\left(\mathrm{m}^{3} / \mathrm{ha}\right)$ for the Cerrado Sensu Stricto in the state of Minas Gerais.

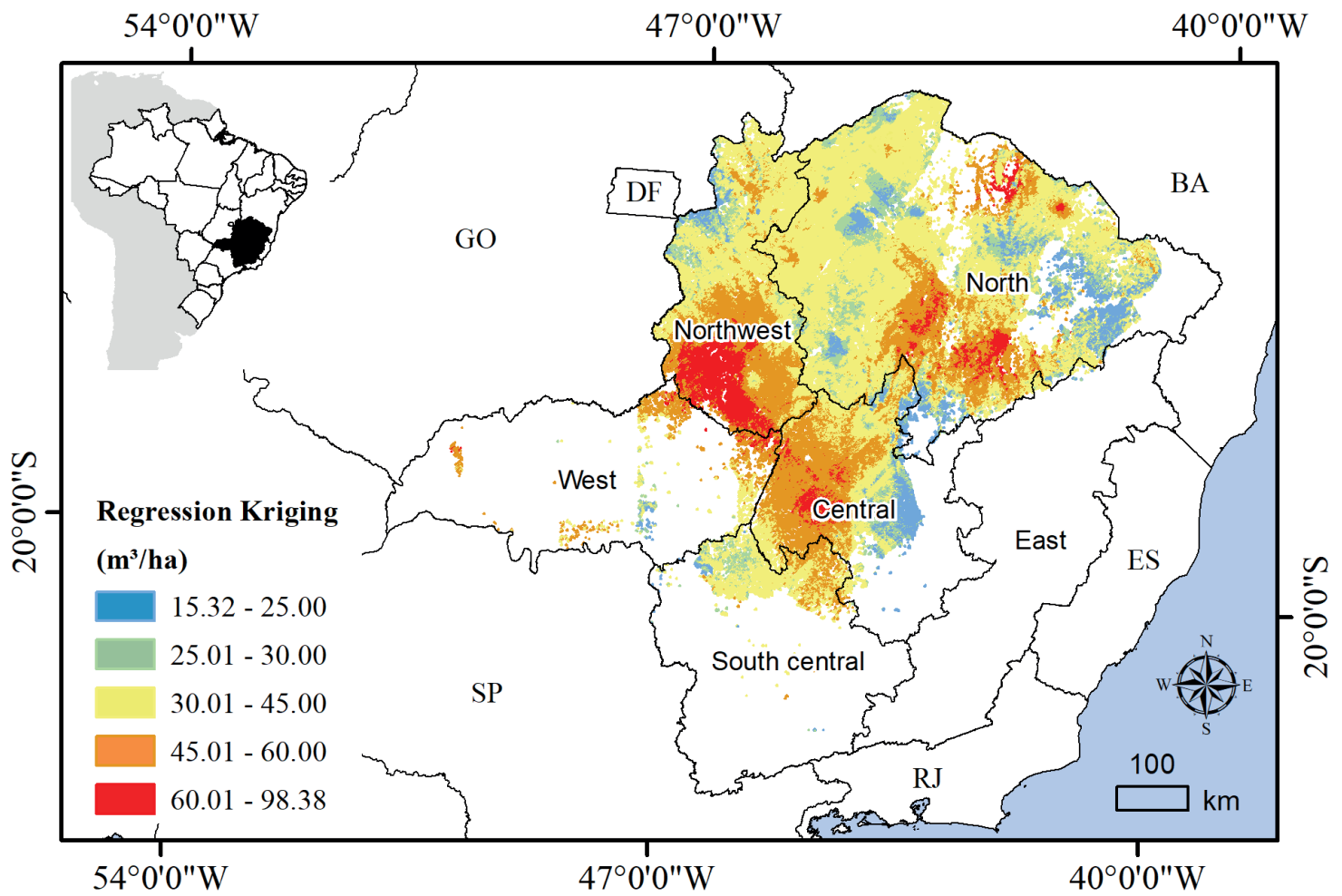

Figure 7 - Map of wood volume $\left(\mathrm{m}^{3} / \mathrm{ha}\right)$ obtained by regression kriging for the Cerrado Sensu Stricto in the state of Minas Gerais. 
on the precipitation regime in the east of Minas Gerais, impeding the transportation of moisture from the Atlantic Ocean over the mountains. The lower overall humidity and the stronger climate seasonality certainly have a negative impact on plant growth (Esquivel-Muelbert et al. 2016). Additionally, the cold fronts that come from the south of the country affect the Cerrado Sensu Stricto region in Minas Gerais, causing a decrease in humidity in the winter months and thus reduced favourability for plant growth.

Regarding the northern part of the state, the effect of the seasonality of precipitation is remarkable. Also, the edaphic component plays an important role in vegetation structure. Therefore, despite the presence of 'enclaves' of highly fertile soils, where dry forests predominate (Apgaua et al. 2014; Santos et al. 2012), there is a general trend towards sandier soils, like the Cambisol (Inceptsols) and Lythollic Neossol. These soils generally have low fertility that, together with the physical characteristics of the soils, low precipitation and high temperatures, create conditions that are unfavourable for plant growth in almost all of the São Francisco River basin. This basin accounts for $35 \%$ of the state area, and is the region with the largest remnants of the Cerrado in the state of Minas Gerais.

\section{CONCLUSIONS}

The predicted wood volume distribution of the Cerrado Sensu Stricto is characterized by high variability, ranging from 15.32 to $98.38 \mathrm{~m}^{3} \mathrm{ha}^{-1}$, and a climatically driven gradient of decreasing wood volume in the southeast-northwest direction, due to the effects of precipitation and temperature seasonality. The deforestation density map also played an important role in explaining the variation in Cerrado Sensu Stricto wood volume throughout the state.
The high variability of wood volume in this vegetation type reinforces the importance of the use of methods that consider the influence of environmental variables on the spatial distribution of wood volume.

\section{ACKNOWLEDGMENTS}

The authors would like to thank Coordenação de Aperfeiçoamento de Pessoal de Nível Superior Brasil (CAPES) for financing part of this study (Finance Code 001). The authors are grateful for comments and suggestions during the review process, which were helpful in improving the paper.

\section{AUTHORS CONTRIBUTIONS}

All authors contributed substantially to the work reported here. EMOS, AAR, and MCNST analysed, interpreted the data, and wrote the manuscript. KDW, JMM, FWAJ, ACFF, and CRM reviewed and edited the manuscript. All authors read and approved the final manuscript.

\section{REFERENCES}

AGUIAR APD ET AL. 2012. Modeling the spatial and temporal heterogeneity of deforestation-driven carbon emissions: The INPE-EM framework applied to the Brazilian Amazon. Global Change Biol 18: 3346-3366.

ALVARENGA LHV, MELLO JM, GUEDES ICL AND SCOLFORO JR. 2012. Performance of stratification in a Brazilian savanna fragment by using geoestatistical interpolator. Cerne 18: 675-681.

APGAUA DMG, SANTOS RM, PEREIRA DGS, MENINO GCO, PIRES GG, FONTES MAL AND TNG DYP. 2014. Beta-diversity in seasonally dry tropical forests (SDTF) in the Caatinga Biogeographic Domain, Brazil, and its implications for conservation. Biodivers Conserv 23: 217232.

ARANTES AE, FERREIRA LG AND COE MT. 2016. The seasonal carbon and water balances of the Cerrado environment of Brazil: Past, present, and future influences of land cover and land use. ISPRS J Photogramm 117: 66-78.

BERNER LT AND LAW BE. 2016. Plant traits, productivity, biomass and soil properties from forest sites in the Pacific Northwest, 1999-2014. Sci Data 3: 160002. 
CAMBARDELLA CA, MOORMAN TB, PARKIN TB, KARLEN DL, NOVAK JM, TURCO RF AND KONOPKA AE. 1994. Field scale variability of soil properties in central Iowa soils. Soil Sci Soc Am J 58: 1501-1511.

CARVALHO LMT AND SCOLFORO JRS. 2008. Inventário Florestal de Minas Gerais - Monitoramento da Flora Nativa 2005-2007. Lavras: Editora UFLA, 357 p.

CRESSIE N. 1991. Statistics for Spatial Data: Wiley Series in Probability and Statistics, $900 \mathrm{p}$.

DORMANN CF ET AL. 2012. Collinearity: a review of methods to deal with it and a simulation study evaluating their performance. Ecography 36: 27-46.

ESQUIVEL-MUELBERT A ET AL. 2016. Seasonal drought limits tree species across the Neotropics. Ecography 40: 618-629.

ESRI - ENVIRONMENTAL SYSTEMS RESEARCH INSTITUTE. 2010. ArcGIS Desktop: Release 10.1. Redlands, CA: ESRI.

FEARNSIDE PM. 2001. Soybean cultivation as a threat to the environment in Brazil. Environ Conserv 28: 23-38.

FERREIRA LG, YOUHIOKA H, HUETE A AND SANO EE. 2004. Optical characterization of the Brazilian Savanna physiognomies for improved land cover monitoring of the cerrado biome: Preliminary assessments from an airborne campaign over an LBA core site. J Arid Environ 56: 425447.

GALEANA-PIZAÑA JM, LÓPEZ-CALOCA A, LÓPEZQUIROZ P, SILVÁN-CÁRDENAS JLAND COUTURIER S. 2014. Modeling the spatial distribution of above-ground carbon in Mexican coniferous forests using remote sensing and a geostatistical approach. Int J Appl Earth Obs 30: 179-189.

GIZACHEW B, SOLBERG S, NÆSSET E, GOBAKKEN T, BOLLANDSAS OL, BREIDENBACH J, ZAHABU E AND MAUYA EW. 2016. Mapping and estimating the total living biomass and carbon in low-biomass woodlands using Landsat 8 CDR data. Carbon Balance Manag 11: $1-14$.

GUEDES ICL, MELLO JM, SILVEIRA EMO, MELLO CR, REIS AAAND GOMIDE LR. 2015. Continuidade espacial de características dendrométricas em povoamentos clonais de Eucalyptus sp. avaliada ao longo do tempo. Cerne 21: 527-534.

HIJMANS RJ, CAMERON SE, PARRA JL, JONES PG AND JARVIS A. 2005. Very high resolution interpolated climate surfaces for global land areas. Int J Climatol 25: 19651978.

HOEKSTRA JM, BOUCHER TM, RICKETTS TH AND ROBERTS C. 2005. Confronting a biome crisis: Global disparities of habitat loss and protection. Ecol Lett 8: 2329.

ISAAKS EH AND SRIVASTAVA RM. 1988. Spatial continuity measures for probabilistic and deterministic geostatistics. Mathematical Geology 20: 313-341.
MCBRATNEY A AND WEBSTER R. 1986. Choosing functions for semi-variograms of soil properties and fitting them to sampling estimates. J Soil Sci 37: 617-639.

MELLO CR, VIOLA MR, BESKOW S AND NORTON LD. 2013. Multivariate models for annual rainfall erosivity in Brazil. Geoderma 202-203: 88-102.

MENG Q, CIESZEWSKI C AND MADDEN M. 2009. Large area forest inventory using Landsat ETM+: A geostatistical approach. ISPRS J Photogramm 64: 27-36.

MEUSBURGER K, STEEL A, PANAGOS P, MONTANARELLA L AND ALEWELL C. 2012. Spatial and temporal variability of rainfall erosivity factor for Switzerland. Hydrol Earth Syst Sc 16: 167-177.

MYERS N, MITTERMEIER RA, MITTERMEIER CG, FONSECA GAB AND KENT J. 2000. Biodiversity hotspots for conservation priorities. Nature 403: 853-858.

OLIVEIRA-FILHO AT AND RATTER JA. 2002. Vegetation physiognomies and woody flora of the Cerrado Biome. In: Oliveira PS and Marquis RJ (Eds), The Cerrados of Brazil: Ecology and Natural History of a Neotropical Savanna, Columbia University Press: New York. p. 91-120.

PALMER DJ, HÖCK BK, KIMBERLEY MO, WATT MS, LOWE DJ AND PAYN TW. 2009. Comparison of spatial prediction techniques for developing Pinus radiata productivity surfaces across New Zealand. Forest Ecol Manag 258: 2046-2055.

R CORE TEAM. 2016. R: a language and environment for statistical computing. Vienna: R Foundation for Statistical Computing.

REIS AA, MELLO JM, ACERBI-JÚNIOR FW AND CARVALHO LMT. 2015. Estratificação em cerrado sensu stricto a partir de imagens de sensoriamento remoto e técnicas geoestatísticas. Sci For 43: 377-386.

ROCHA GF, FERREIRA LG, FERREIRA NC AND FERREIRA ME. 2011. Detecção de Desmatamentos no Bioma Cerrado entre 2002 e 2009: Padrões, Tendências e Impactos. Rev Bras Cart 63: 341-349.

RUFINI AL, SCOLFORO JR, OLIVEIRA AD AND MELLO JM. 2010. Volume equations for the Savannah (Cerrado), in Minas Gerais state. Cerne 16: 1-11.

SANO EE, ROSA R, BRITO JL AND FERREIRA LG. 2010. Land cover mapping of the tropical savanna region in Brazil. Environ Monit Assess 166: 113-124.

SANTOS RM, OLIVEIRA-FILHO AT, EISENLOHR PV, QUEIROZ LP, CARDOSO DBOS AND RODAL MJN. 2012. Identity and relationships of the Arboreal Caatinga among other floristic units of seasonally dry tropical forests (SDTFs) of north-eastern and Central Brazil. Ecol Evol 2: 409-428.

SCHWIEDER M, LEITÃO PJ, BUSTAMANTE MMC, FERREIRA LG, RABE A AND HOSTERT P. 2016. Mapping Brazilian savanna vegetation gradients with Landsat time series. Int J Appl Earth Obs 52: 361-370. 
SCOLFORO JRS, MELLO JM AND OLIVEIRA AD. 2008. Inventário florestal de Minas Gerais: Cerrado, florística, diversidade, similaridade, distribuição diamétrica e de altura, volumetria, tendências de crescimento e áreas aptas para manejo florestal. Lavras: UFLA, 216 p.

SCOLFORO HF, SCOLFORO JRS, MELLO CR, MELLO JM AND FERRAZ FILHO AC. 2015. Spatial distribution of aboveground carbon stock of the arboreal vegetation in Brazilian Biomes of Savanna, Atlantic Forest and Semiarid woodland. PLoS ONE 10: e0128781.

SCOLFORO HF, SCOLFORO JRS, MELLO JM, MELLO CR AND MORAES VA. 2016. Spatial interpolators for improving the mapping of carbon stock of the arboreal vegetation in Brazilian biomes of Atlantic forest and Savanna. Forest Ecol Manag 376: 24-35.

SILVA JF, FARIÑAS MR, FELFILI JM AND KLINK CA. 2006. Spatial heterogeneity, land use and conservation in the cerrado region of Brazil. J Biogeography 33: 536-548.
SKORUPA ALA, GUILHERME LRG, CURI N, SILVA CPC, SCOLFORO JRS AND MARQUES JJGSM. 2012. Propriedades de solos sob vegetação nativa em minas gerais: Distribuição por fitofisionomia, hidrografia e variabilidade espacial. Rev Bras Cienc Solo 36: 11-22.

TERRA MCNS ET AL. 2018. Water Availability Drives Gradients of Tree Diversity, Structure and Functional Traits in the Atlantic-Cerrado-Caatinga Transition, Brazil. J Plant Ecol 11(6): 803-814.

VIANA H, ARANHA J, LOPES D AND COHEN WB. 2012. Estimation of crown biomass of Pinus pinaster stands and shrubland above-ground biomass using forest inventory data, remotely sensed imagery and spatial prediction models. Ecol Model 226: 22-35.

WAGNER F, ROSSI V, STAHL C, BONAL D AND HÉRAULT B. 2012. Water availability is the main climate driver of neotropical tree growth. PLoS ONE 7: e34074. 